\title{
LEGAL STATUS OF THE CHILD IN UKRAINE
}

\section{Krestovska N. M.}

\section{INTRODUCTION}

The category of the legal status of the child is a relatively new issue of national jurisprudence, notwithstanding the fact that legal rules regarding the upbringing and socialization of children has been existed since the ancient era. During the civilization progress of mankind, the status of the child has undergone a dramatic transformation: from the legal regime of belongings of the family, more precisely, belongings of the head of the family - the father to the status of a legal personality. At the same time, the child as a member of the human community and childhood as a socio-cultural phenomenon have evolved from a purely domestic level to a global problem. Ensuring the proper conditions for the survival, development and socialization of the younger generation has become one of the priorities of the international community, provided by a number of binding universal and regional European humanitarian legal standards. Protection of childhood is seen as a factor of sustainable development that would ensure equal rights of present and future generations in access to all the benefits of nature and civilization.

Obviously, at the national level, the legal status of the child deserves a thorough study, which, in addition to an academic discourse, must be critical, predictive and practically oriented, given the deficiencies of national Juvenile Law noted by scholars and practitioners.

Issues of constitutional legal status of the child has been disclosed in the series of studies ${ }^{1}$, mainly devoted to the rights of the child - the core of the legal status of the child, to legal guarantees of rights of the child, in particular, to protection of the rights of the child. The study of the legal status of the child has been amended by S.P. Kotaleichuk, N.M. Onishchenko, O.M. Opolska and

${ }^{1}$ Кадегроб Л.О. Конституційно-правовий статус дитини в Україні: поняття та особливості. Вісник ОНУ імені І. І. Мечникова. Правознавство. 2018. Т. 23. Вип. 1(32). C. 15-21; Китайка О.В. Гарантії прав і свобод дитини в Україні: поняття та зміст. Науковий вісник Міжнародного гуманітарного університету : зб. наук. пр. Сер. : «Юриспрудениія». 2015. Вип. 13 (1). С. 50-52; Кудрявцева О. М. Конституційно-правові основи захисту прав дитини в Україні : [монографія]. Київ : Арт Економі, 2015. 265 с.; Оржаховська А.А. Конституційно-правовий статус дитини, яка перебуває в спеціальному навчальному закладі соціальної реабілітації : автореф. дис. ....канд.юрид.наук : спец. 12.00.02. Кнїв, 2013. 20 с.; Швець І.В. Конституційно-правовий статус дитини : поняття, елементи, види. Бюлетень Міністерства юстиції України. 2012. № 3. С. 116-123; Шульц О.А. «Права дитини» як категорія сучасного конституційного права. Часопис Київького університету права. 2009. № 3. C. 91-96. 
others from the standpoint of the general theory of $\mathrm{law}^{2}$, but the focus of their research remains the same - the rights of the child protected by the state. One cannot deny the importance of such an approach. On the other hand, we can observe that these studies show the dominance of the paternalistic doctrine in the field of the children's rights. The child in the doctrinal, vocational and everyday legal awareness is regarded as a subject of protection by the state, society, family, without acquiring the qualities of the legal personality. Moreover, scholars still have paid insufficient attention to issues of other components of the legal status of the child, particularly to the duties and responsibility of the child, as well as the attention to the procedural rights of the child still is quite modest. The issue of the correlation between international and national legal norms that shape the legal status of the child remains unexplored. The conventionality of the scholars in determining the constitutional status of the child has not gained yet. Finally, the issues of the structure and substantive content of the legal status of the child, that obviously must include not only the rights of the child and the guarantees of its realization, remain under-researched or debated.

The methodology of the presented research is based, firstly, on an existential and humanistic approach, to be precise, on the understanding of the child as the person who is undergoing the development and formation of a legal personality. The child needs different levels and means of protection, support and partnership at different stages of growing up. The protection must prevail on the stage of early childhood; becoming a youngster, the child is becoming a legal partner of adult members of his/her family and a member of the community. Secondly, the author affirms the difference of the concepts of law and legislation. Therefore, the structure of the legal status of the child includes the rules of positive law as well as the values of natural (social) law. Thirdly, admitting the idea of the autonomy of the child as a subject of law and as a holder of constitutional status, we note the dialectical relationship between the rights of the child and the duties and responsibility of the child. Insufficient attention to this aspect of the legal status of the child increases the number of opponents of the juvenile law and juvenile justice, since the former one is seen as a formalization of child permissiveness and the latter one as a system of forgiveness and even encouragement of juvenile offenders.

${ }^{2}$ Коталейчук С.П. Теоретико-правові проблеми правового статусу неповнолітніх в Україні та забезпечення його реалізації як один із основних напрямків діяльності міліції : автореф. дис. ... канд. юрид. наук: спец. 12.00.01. К., 2004. 20 с.; Костенко Я.В. Правовий статус дитини в національному законодавстві. Актуальні проблем вітчизняної юриспруденції. 2018. № 1. С. 55-60; Оніщенко Н.М., Львова О. Л., Сунєгін С.О. Права і свободи дитини: вступ до проблеми. Часопис Київського університету права. 2013. № 2. С. 13-17; Опольська Н.М. Види прав і свобод дитини. Науковий часопис НПУ імені М.П. Драгоманова. Серія 18 : Економіка і право. 2010. Вип. 8. С. 151-157. 
The sources of the research are the constitutional and sectoral legislation of Ukraine, international and regional European legal acts on the rights of the child.

\section{International scope of the legal status of the child}

Ukraine is a party of the main treaties in the international juvenile law, to be specific:

the Convention on the Rights of the Child (hereinafter - the CRC), ratified by the parliamentary law 27.02.1990;

the Optional Protocol on the Sale of Children, Child Prostitution and Child Pornography (hereinafter - the OPSC), ratified by the parliamentary law 03.04.2003;

the Optional Protocol on the involvement of children in armed conflict (hereinafter - the OPAC), ratified by the parliamentary law 23.06.2004;

the Optional Protocol on a Communications Procedure, ratified by the parliamentary law 16.03.2016.

The CRC is the most comprehensive international human rights treaty relating to children. Article 1 of the CRC defines a child as "every human being below the age of eighteen years unless under the law applicable to the child, majority is attained earlier”. This notion is implemented in the national juvenile law as well as the main principles of the CRC.

Ukraine is a party of the main European treaties in the branch of juvenile law, to be specific:

The European Convention on the Legal Status of Children Born out of Wedlock (ETS № 85), ratified by the parliamentary law 14.01.2009;

The European Convention on Recognition and Enforcement of Decisions concerning Custody of Children and on Restoration of Custody of Children (ETS № 105), ratified by the parliamentary law 06.03.2008;

The European Convention on the Exercise of Children's Rights (ETS № 160), ratified by the parliamentary law 03.08.2006;

The European Convention on Contact concerning Children (ETS № 192), ratified by the parliamentary law 20.09.2006

The European Convention on the Protection of Children against Sexual Exploitation and Sexual Abuse (ETS № 201), ratified by the parliamentary law 20.09.2006;

The European Convention on the Adoption of Children (Revised) (CETS 202), ratified by the parliamentary law 04.05.2011.

It should be noted that national law recognises the priority of the international law in the field of the rights of the child. Mostly of the abovementioned conventions are implemented into the acts of national legislation. Thus, the provisions of the European Convention on the Exercise of the Children's Rights amend the Family Code of Ukraine and therefore provide 
the procedural rights of a minor, such as: to express his/her opinion directly or through a representative or legal representative; to receive information about the trial through a representative or legal representative; exercise other procedural rights and perform procedural obligations under the international treaties, that have been ratified by the Verkhovna Rada of Ukraine.

The provisions of the European Convention on Contact concerning Children are implemented into the Law of Ukraine "On Protection of Childhood" (hereinafter - Child Protection Law) and guarantee the realization of the right of the child to contact parents, other family members and relatives who live separately, including those persons in different states.

\section{The general legal status of the child}

The domestic constitutional doctrine traces the tendency to equate the constitutional and general legal status of the child. The example of this position is presented by O.V. Sinegubov who defines the general status of a child "as a citizen of a state enshrined in the Constitution. It is universal, generalized and uniform for all children, regardless of nationality, religious beliefs, or social status. It is characterized by stability and certainty, implies equality of rights and obligations of citizens, equality before the law, and also demonstrates the social value of a person”3. In our opinion, such an identification of the general and constitutional status of the child leaves the international legal status of the child "overboard", as well as the values of childhood and the child reflected in natural (social) law.

In our opinion the categories of the child's general legal status and the child's constitutional status are not identical, and the relationship between them can be described as a complex relation between the whole and the part where the part acts as a centre, in turn derived from the internationally recognized concept of the rights of the child, above all, the four fundamental principles of the CRC: non-discrimination and equal rights for children; ensuring the best interests of the child; ensuring the right to survival and development; respecting the views of the child.

The general legal status of the child in Ukraine is defined in numerous, unfortunately, not always substantively agreed sources of both national, international and European regional law. In their hierarchy, the CRC, the Constitution of Ukraine, and the Law of Ukraine "On Childhood Protection" come first. In addition, the legal status of the child has its value dimension: humanity recognizes not only children but also childhood as a legal value, conditioned by the unique attributes of the child, which are: innocence, vulnerability, energy, hope, questioning stated by the World Declaration on

${ }^{3}$ Синєгубов О.В. Правовий статус дитини, як учасника особистих немайнових відносин. Форум права. 2013. № 1. С. 903 
the Survival, Protection and Development of Children, agreed at the World Summit for Children on 29-30 September 1990 (point 2) ${ }^{4}$.

Given the abovementioned, we define the general legal status of the child (general juvenile status) as a system of human rights, freedoms and interests, duties and responsibilities of the special subject of law - the child expressed in the values of natural law and the positive legal norms, and guaranteed by society and the state.

The general legal status of the child is the basis of the sectoral and special statuses of the child. The sectoral (family, civil, etc.) status of the child, normatively expressed in the relevant sectoral legal acts.

The special status of the child arises in a social context that is atypical, special and exceptional and, as a consequence, modifies the child's general legal status. As to the current juvenile legislation of Ukraine, these are the statuses of 1) orphans and children deprived of parental care; 2) homeless children; 3) disabled children and children with intellectual or physical disabilities; 4) children affected by natural disasters, technogenic accidents, and catastrophes; 5) children affected by HIV infection and children with other incurable and serious illness; 6) refugee children; 7) children - victims of violence; 8) juvenile offenders.

As to the recent changes of juvenile law implemented by the Law of 26 January $2016^{5}$, the system of special juvenile statuses has been expanded and has become more complicated. The law introduced new concepts: "a child who is in difficult circumstances" and "children who need special protection of the state". The first one is a child who is in a condition that adversely affects his/her life, health and development: disability, serious illness; homelessness; conflict with the law; involvement in the worst forms of child labour; addiction to psychotropic substances and other types of addiction; domestic violence and abuse; evasion of parents or custodians from the performance of their parental duties; natural disasters, technogenic accidents, catastrophes; circumstances of hostilities or armed conflict (article 1). As we can see, the number of special statuses of the child has increased, but at the same time, the same Child Protection Law has used different terminology to refer clearly to the same phenomena.

The system of special juvenile statuses appears to be the following: 1) the status of children with special needs in health care and access to education; 2) status of homeless children; 3) the status of children in conflict with the law; 4) the status of children involved in the worst forms of child

${ }^{4}$ World Declaration on the Survival, Protection and Development of Children, 1990. URL: https://www.unicef.org/wsc/declare.htm.

${ }^{5}$ Про внесення змін до деяких законодавчих актів України щодо посилення соціального захисту дітей та підтримки сімей з дітьми: Закон України від 26.01.2016 № 936-VIII. Відомості Верховної Ради Украӥни. 2016. № 10. Ст. 99. 
labour; 5) the status of children addicted to alcohol, psychotropic substances, etc .; 6) the status of children who are victims of violence and abuse (at home, at school, boarding school, etc.); 7) the status of orphans; 8) the status of children deprived of parental care; 9) the status of children suffering from natural disasters, man-made accidents, catastrophes; 10) the status of children affected by war or armed conflict; 11) the status of refugee children.

Despite the large number of researches in the field of rights of the child, the structure of legal status of the child is still a matter of discussion. S.P. Kotaleychuk defines it as a set of: a) the rights and freedoms of the child; b) the duties and responsibility for their failure or breach; c) guarantees of the rights and freedoms ${ }^{6}$. Joining this view, A.A. Orzhakhovska formulates legal status of the child is as a system of rights and freedoms, given to the child from birth, duties and accountabilities, and its scope is increasing while the child is growing up ${ }^{7}$. O.V.Kytaika includes the system of rights, freedoms and duties of the child to the general (constitutional) status of the child ${ }^{8}$. And the restrictive vision of the structure of the legal status of the child (the rights and duties of the child) is offered by O.M.Kudryavtseva ${ }^{9}$.

In our opinion, the structure of the general legal status of the child should be analysed in the light of the legal capacity of the child.

A peculiarity of a child's legal capacity is its developing dynamic character, with a general tendency to "fill" its scope as the child is growing up. A new-born baby is just a passive bearer of the rights to life, name, parental care and upbringing. Passing the socialization, the child is learning to perform legal actions, to make legal decisions, and to enter legal relations.

The contemporary psychology has abandoned the idea of the child as a "blank slate", as well as the pedagogy refutes the idea of the child as a potential, not actual, person. Even the youngest children have the consciousness, the will and the ability to carry out actions that often are legal. In this regard, the ability of the child to be a bearer of rights should obviously be interpreted as an emerging opportunity. Children, unlike adults, are not able to enjoy some rights (such as suffrage). In other words, their legal capacity and the legal capacity of the adult differ. However, a child's legal capacity is not limited, since restriction of the legal capacity may be set only by a court decision. And vice versa, the child is a bearer of legal qualities, that are not immanent to adults.

It is proposed to consider the relationship between the child's capacity and the capacity of the adult as a complex phenomenon that combines similar

\footnotetext{
${ }^{6}$ Коталейчук С.П. Вказ. праця. С. 25-26.

${ }^{7}$ Оржаховська А.А. Вказ. праця.

${ }^{8}$ Китайка О. Генезис конституційно-правового статусу дитини. С. 138.

${ }^{9}$ Кудрявцева О. Конституційні засади захисту прав і свобод дитини в Україні: досвід, проблеми, перспективи. Історико-правовий часопис. 2014. № 1. С. 49-53.
} 
and different features. The structure of the legal capacity of the child and the adult is similar, the difference consists in its scope.

The rights and duties of the children are the core of their legal status, and they determine all other components. The legal capacity and guarantees of the child's legal status matter only in case the child's rights and duties have been formally defined.

In our opinion, the natural and positive rights and freedoms of the child should be distinguished. Rights of the child are, first of all, human rights that are applied to everyone, irrespective of age, gender, nationality or other characteristics. Therefore, the child has mostly the same natural rights that adults have. The natural rights of the child should are enshrined in the Declaration of the Rights of the Child, such as the following rights: the right to the parental love, the right to play and recreation (Principles 6 and 7) ${ }^{10}$. It is an indisputable fact that we can not formalize every natural right, at least, today. In that sense, the constitutional provision on the non-exhaustive characteristic of the human rights category should be understood.

In the formalization of the child's natural rights, in our opinion, the category of interests of the child must be helpful. The juvenile legislation of Ukraine uses the terms "best interests of the child", "interests of the child", "legitimate interests of the child". The first of these terms appears to be teleological and applicable mainly to the interpretation and evaluation of legal and policy acts concerning children. It is in this sense that it is one of The fundamental principle of the CRC, which states: "In all actions concerning children, whether undertaken by public or private social welfare institutions, courts of law, administrative authorities or legislative bodies, the best interests of the child shall be a primary consideration” (part 1, article 3 ).

The term "legitimate interest of the child", according to the official interpretation of the Constitutional Court of Ukraine, is similar to the term "protected by law" and means "the desire to use specific tangible and/or intangible goods determined by the general content of the objective law and not directly mediated in the individual right that is a simple legitimate permission and a separate object of judicial protection and other legal remedies in order to meet individual and collective needs, which are not contrary to the Constitution and laws of Ukraine such as the public interest, fairness, honesty, reasonableness and other law principles"11. Among such

${ }^{10}$ Declaration of the Rights of the Child. Adopted by UN General Assembly Resolution 1386 (XIV) of 10 December 1959. URL: http://www.un.org/cyberschoolbus/humanrights/ resources/child.asp.

${ }^{11}$ Рішення Конституційного Суду України у справі за конституційним поданням 50 народних депутатів України щодо офіційного тлумачення окремих положень частини першої статті 4 Цивільного процесуального кодексу України (справа про охоронюваний законом інтерес) 1 грудня 2004 р. № 18-рп/2004. Офіційний вісник України. 2004. № 50. Ст. 3288. 
legitimate interests of the child should be mentioned the interest in health care, physical and spiritual development, education. Violation of the legitimate interests of the child is the basis for the child's appeal to the authorities and services in matters of children, the legal responsibility of parents and so on.

And finally, the term "child's interest" is used in the sense of the child's welfare conditions that provided largely without the involvement of the state, usually by parents / adoptive parents / guardians / custodians, at their discretion, taking into account the presumption of parental love and care for the children. In this regard the child's interests are an individualized legal reflection of the natural law values.

Thus, as to the juvenile law of Ukraine, the general legal term "interest" defines the various facets of the child's legal capacity and the responsibilities of the parents, the state, and public institutions.

As for the legal duties and accountabilities of the child, according to the general legal principle enshrined in the Constitution of Ukraine, "The legal order in Ukraine is based on the principles according to which no one shall be forced to do what is not envisaged by legislation" (article 19). Therefore, the duties and accountabilities of the child can only be positive.

It looks correct to regard legal liability as a component of the legal status of the child, considering that the legal liability is a special kind of legal duty.

In our opinion, the structure of the child's legal status, given his/her physical and intellectual immaturity, should include guarantees of the fulfilment of the child's duties as well as guarantees of respect for the rights of the child. Thus, in particular, legal education of the child, that is, forming his/her knowledge of the rights and duties, skills and abilities to implement the rules of law and a stable attitude to lawful behaviour should become the general guarantee of the exercise of rights and duties of the child. For example, the secondary education is mandatory for everyone in Ukraine. Thus free of charge and accessible education at state and municipal educational institutions is a guarantee for children who exercise this constitutional duty.

\section{The Constitutional status of the child in Ukraine}

First of all, we note several approaches to resolving the issue of the constitutional status of the child in the domestic constitutional doctrine: they should be called narrow and broad. Thus, according to the first approach A.A. Orzhakhivska define constitutional status of the child as a set of rights, freedoms and duties stipulated by the Basic Law of Ukraine and exercised by persons under the age of maturity.

Instead, I.V. Shwetz defines the constitutional status of the child as a legally enshrined position of the child in society determined by the system of principles and norms contained in the Constitution of Ukraine, international 
acts and other legal acts, and, therefore, protecting the rights, freedoms and duties of the child, as well as guaranteeing its implementation and responsibility. It should be noted that the last definition covers not only the constitutional rules but also all other, particularly international legal norms. Such a definition, in terms of its regulatory scope, approximates the general legal status of the child. Therewith the definition is characterized by severe paternalism, because, according to the author, the constitutional status of the child is made up exclusively of norms of a protective nature.

Finally, it should be stated the refusal to determine the constitutional status of the child and focus on the analysis of its elements, as it was demonstrated by the author of a recent comparative legal study of the status of children under the constitutional legislation of Ukraine and Hungary ${ }^{12}$.

In our opinion, the constitutional status of a child in Ukraine is a system of formally defined rights, duties and responsibility of the child as a regular member of Ukrainian civil society that are enshrined in the Basic State Law. In this regard, it is worth agreeing with those researchers who regard that a child has all the rights and freedoms that every person has under the Constitution of Ukraine. In particular, O.F.Skakun submits a classification of the rights of the child, noting that they are largely related to human rights ${ }^{13}$. O.A. Schulz notes that constitutional provisions governing the rights and freedoms of the person and citizen, without defining a specific subject (the legislator uses the term "everyone"), determine the legal status of the child in Ukraine $^{14}$, and M.A. Manina points out that almost all human rights apply to the child, but with certain characteristics in mind ${ }^{15}$.

O.V. Kytaika use the following dichotomy of the constitutional rights of the child:

a) constitutional rights that provide decent physical existence of the child;

b) the constitutional rights that provide proper intellectual and moral development of the child ${ }^{16}$.

Adaptation of constitutional norms that are common to all people living or residing in Ukraine in relation to the child, is usually proceeded by juvenile and other sectoral legislation in the following forms:

12 Губаль Ю.В. Конституційно-правовий статус дитини в Україні та Угорщині: порівняльно-правове дослідження : автореф. дис. ... канд. юрид. наук : 12.00.02. Ужгород, 2015. $14 \mathrm{c}$.

${ }^{13}$ Скакун О.Ф. Теорія держави і права (Енциклопедичний курс) : підручник. Харків : Еспада, 2006. С. 225.

${ }^{14}$ Оржаховська А.А. Вказ. праця.

${ }^{15}$ Маніна М. А. Особисті права дитини. Актуальні проблеми вітчизняної юриспрудениії. 2013. Вип. 4. С. 50 (С. 49-56).

${ }^{16}$ Китайка О.В. Конституційно-правовий статус дитини в Україні та міжнародні ювенально-правові стандарти: автореферат дис. ...канд. юрид. наук. 12.00.02. Одеса, 2018. C. 16. 
expanding the content of the legal provision for the benefit of the child. For example, the right to an adequate standard of living for the adult means adequate nutrition, clothing and shelter, and for the child means not only the tangible but also the intangible benefits that are required for his/her physical, intellectual, moral, cultural, spiritual and social development. The concept of child abuse is also widespread;

limitation of the content of the legal provision for the protection of the child (for example, the right of children to association is restricted only by NGOs - children are not allowed to join political parties);

setting additional age limits (only children who are sixteen years of age enjoy the right to business);

establishing specific guarantees for the exercise of rights and freedoms (for example, state bodies monitor the observance of the rights of the child in the sale of housing);

establishing special regimes for the exercise of the rights and freedoms of children who are in an unfavourable or extreme situation. Thus, the state is obliged to provide children with intellectual or physical disabilities the necessary conditions for a fulfilling life, in particular - for education, and creates special procedural guarantees for the rights of children in conflict with the law.

Inasmuch as the constitutional human rights and the rights of the child coincide, S.P. Kotaleychuk distinguishes the following groups of children's rights:

personal rights: the right to life; the right to protection against all forms of violence; the right to respect for honour and dignity; the right to freedom of expression, ideology and religion; the right to name and citizenship;

economic rights: the right to property; the right to business; the right to labour; the right to use the objects of public property; the right to social security; cultural rights: the right to free development of the individual; the right to freedom of association in public organizations (participation in cultural and creative life); the right to education ${ }^{17}$.

However, S.P. Kotaleychuk denies political rights of the children, and this conclusion should be considered as discursive. As to the content of Article 40, the Constitution of Ukraine implies, children have the right to apply to state authorities and local self-government bodies, enterprises, institutions, organizations, mass media on an equal basis with all other individuals. It should be noted that this right is one of the child's poorly adapted human rights characteristics. Only the order of petitions in case of ill-treatment, negligence or abuse is specified for the child. In this regard, the recent accession of Ukraine to the Optional Protocol to the CRC on a Communi-

\footnotetext{
${ }^{17}$ Коталейчук С.П. Вказ. праця. С. 49-70.
} 
cations Procedure under which the child or his/her representative has the right to file an individual complain to the Committee on the Rights of the Child about violation of the children's' rights that are protected by the CRC or its optional protocols.

The right of children to association in public organizations (which the abovementioned author attributes to cultural rights) is defined, along with other citizens, with Article 36 of the Constitution of Ukraine and specified by the Law of Ukraine "On Youth and Children's NGOs"18. The content of this right of the child is: the right to establish a child or youth organization; membership in a child or youth organization; participation in drafting and discussing decisions on the public policy on children and youth.

To differentiate such a component of the general and constitutional status of the child as the rights and freedoms of the child, it is helpful to use the dichotomy of human rights and freedoms adapted to the child and juvenile rights and freedoms that are defined by objective law (international and national) as specific to the children only, namely:

the right to live in the family;

the right to have a child communicate with parents who live separately from the child, including those who live in another country;

the right to receive information about absent parents, if it does not harm his/her mental and physical health;

the right to state maintenance and placement in case of deprivation of parental care.

The Constitutional Law guarantees the juvenile rights and freedoms without detailing its content. Thus, the Constitution of Ukraine guarantees the state protection of the family, childhood, motherhood, and paternity (Part 3, Article 51). In our opinion, the economy and the conciseness of the relevant provisions of the Constitution are justified and understood from the standpoint of a historical and political interpretation of the constitutional provisions. It should be noted, that the Constitution of Ukraine was adopted at a time when the main humanitarian standard - the CRC - had already been ratified by Ukraine and it had been implemented. The inclusion of provisions of the CRC to the Constitution would only lead to its duplication.

Unlike the rights and freedoms, the provisions that set the duties of children are not systematic in Ukraine, sometimes vaguely defined and poorly adapted to the child. As for juvenile duties, they have not been adequately expressed. Some authors affirms that including constitutional duties to the constitutional status of the child is inappropriate ${ }^{19}$.

${ }_{18}$ Про молодіжні та дитячі громадські організації: Закон України від 1 грудня 1998 р. Відомості Верховної Ради Украӥни. 1999. № 1. Ст. 2.

${ }^{19}$ Китайка О.В. Конституційно-правовий статус дитини в Україні та міжнародні ювенально-правові стандарти. С. 11-12. 
Author of one of the few works on the duties of the child, M.A. Manina classifies constitutional duties of the child into four groups:

duties that are directly related to the exercise of the rights of the child and are performed by others (for example, duty to maintain a child);

duties that children carry out, but their implementation depends on the actions of others (e.g., secondary education);

duties that are directly fulfilled by children and their implementation is independent of the child's age;

duties that are directly implemented by children and their implementation depends on the child's age ${ }^{20}$.

It seems that the first abovementioned group of the duties cannot be included in the legal status of the child as the duties, rather, it is a guarantee of respect for the rights of the child. As for the third and fourth groups of duties, the distinction emphasizes the existential nature of the child's status, that is, his/her mobility: as the child is growing up, it is filling with new components.

The constitutional duties of the child as a person and a citizen, include:

protection of the Motherland, independence and territorial integrity of Ukraine (this duty rests solely on male juveniles and means preparatory training and enrolment in conscript precincts). In particular, Ukraine's accession to the OPAC guarantees that children are not called up for military service or any other involvement in carrying weapons;

respect for state symbols of Ukraine;

protection of nature and cultural heritage;

payment of taxes and fees;

observance of the legislation of Ukraine;

completing general secondary education. Mainly, this constitutional requirement applies to children, although the Constitution of Ukraine does not contain a special reservation.

The concept of the specific duties of the child seems like a gap in Ukrainian Juvenile law comparing the issue with the foreign legal experience. The duty of the to honor their parents always and to aid, support and protect them when they need it is enshrined in the American Declaration of Human Rights (Article XXX). The the Law of the Republic of Azerbaijan on the Rights of the Child establishes the following system of duties of the child: "The child is obliged to observe the rules of behaviour in the society, to know the state attributes of the Republic of Azerbaijan, to acquire knowledge, to prepare him/herself for useful activities, to honor his/her parents, to respect rights and interests of other citizens, to preserve the monuments of history and culture, to protect the environment, to perform other duties stipulated by the legislation of the Republic of Azerbaijan. In order to make children aware of their duties and to fulfil them, parents, as well

${ }^{20}$ Маніна М. До питання про конституційні обов'язки дітей. Право України. 2007. № 11. C. 43. 
as representatives of the relevant authorities and educational institutions, conduct outreach and advocacy work for children"21.

The Constitution of Ukraine imposes on parents the duty to maintain children until their maturity (article 51). This constitutional duty seems to be also applied to minor parents, and it should be noted that sectoral legislation demands assisting underage parents in exercising parental rights and duties. If the mother, the father of the child is a minor, the grandmother, grandfather of the child of the parent who is a minor are obliged to assist him/her in the exercise of his/her parental rights and the fulfilment of parental duties (Article 16, the Family Code of Ukraine) ${ }^{22}$. The liability of the underage parents is also actual ${ }^{23}$.

In general, the constitutional regulation of the child's duties must be considered as sufficiently complete, with a clause: the fulfilment of the child's duties should be guaranteed by the state as well as the respect for the rights and freedoms of the child, taking into account the peculiarities of the child's legal personality. This clause is especially important for the such a kind of duty as the legal liability of the child. As for adults, the Constitution of Ukraine contains only general principles of legal liability of the child, namely: the principle non bis in idem; the individual nature of legal liability; the right not to testify against himself; the presumption of innocence; the presumption of knowledge of the law. Specific regulation of legal liability of children is concentrated in sectoral legislation. Along with the typical types of legal liability (criminal, administrative, civil, labour) today it is possible to speak about the separation in the general legal status of a child of a special, peculiar only to its type - juvenile liability ${ }^{24}$.

Such a component of the constitutional status of the child as its guarantees is evaluated by domestic researchers in different ways: from "filing" to it all public and state methods, means, forms of securing the rights of the child, and even regarding guarantees as the basis of the constitutional legal status of the child ${ }^{25}$ to the limitation of their system by provisions of the Constitutional Law only. O.V. Kytaika defines them as a system of constitutional means of the realization, and protection of the rights and freedoms of a minor that partially coincide with the guarantees of the rights and freedoms of the individual, and differentiates legal and organizational guarantees of respect for the rights of the child ${ }^{26}$.

${ }^{21}$ О правах ребенка: Закон Республики Азербайджан от 19 мая 1998 г.

${ }_{22}$ Сімейний кодекс України. Відомості Верховної Ради Украӥни. 2002. № 21-22. Ст. 135.

23 Дутко А.О., Куліш Г.О. Сімейно-правовий статус батьків, які не досягли повноліття. Юридичний науковий електронний журнал. 2019. № 1. С. 69.

24 Грігорова Г.Л. Ювеналістична концепція реалізації негативної юридичної відповідальності неповнолітнім в Україні. Науковий вісник МГУ. Сер. : Юриспруденція. 2014. Вип. 10-1. С. 39-41.

${ }^{25}$ Кудрявцева О. Конституційні засади захисту прав і свобод дитини в Україні: досвід, проблеми, перспективи. Історико-правовий часопис. 2014. № 1. С. 53.

${ }^{26}$ Китайка О.В. Гарантії прав і свобод дитини в Україні. С. 52. 
From our viewpoint, the security of the child's legal status, firstly, must not be a duty of the state only, but also a duty of the society and its institutions, in particular, the family, as required by the principle of the best interests of the child enshrined in the CRC. Meanwhile, the Constitution of Ukraine "reserves" it for the state: "Family, childhood, motherhood and paternity are protected by the state" (part 3, article 51). Secondly, as it was mentioned above, guarantees should extend not only to the rights and freedoms, but also to the duties and liabilities of the child, which are provided by the Constitution of Ukraine generally, and in our view require a regulatory definition. The constitutional status of the child must balance between ideas of protecting the rights and interests of the child and independence of the child's personality in legal relations.

\section{The sectoral legal statuses of the child}

There are several sectoral statuses of the child under the provisions of Ukrainian law, and the most important ones are the following: the family status, the educational status, the procedural status of the child.

The status of the child under Chapter 13 of the Family code includes the following rights of the child: the right to name and patronymic; the right to change surname; the right to live in the family and to be raised in the family; the right to know his/her parents; the right to parental support and care; to contact parents and other relatives they if live separately; the right to choose residence, the right to his/her opinion. Every right corresponds to the certain duty of the parent or the substitute parent.

In case of deprivation of parental care, the child is entitled to maintenance and placement by the state. The forms of placement of deprived children under the Family law are the following:

family forms - adoption, guardianship and care;

quasi-family forms - patronage; foster family; family-type orphanage;

extra-family forms - child custody in the state orphanage.

The issue of the family duties of the child is discursive to the certain extent ${ }^{27}$. The idea of their absence in the family looks attractive inasmuch they are not defined in the Family code.

In our opinion, the respect to the child and integrity of the status of the child as a member of the family and the member of the society requires supplementing the Family code with the duties of the child. L.P. Korotkova suggests the following notion of the child's duties in the family: "Children are obliged to respect their parents, to care of them and to help them as far as possible”. In addition, she proposes to supplement the Family legislation with

${ }^{27}$ Найман Н. Сімейно-правовий статус дитини. Підприємницчтво, господарство $i$ право. 2016. № 6. С. 42. 
a duty of a minor who lives with the family and has an independent income, to participate in the family budget ${ }^{28}$.

The core of the educational status of the child is the right to education. In Ukraine, the education of children is carried out in the forms of school, preschool and extra-curricular education. The specific feature of the school education is its mandatory nature, therefore the right to education is regarded as a duty of the child as well. This duty of the child is specified by the duties of the pupil:

to fulfil the requirements of the educational program (individual curriculum if available), in accordance with the principle of academic integrity, and to achieve the results of training provided by the standard of education for the appropriate level of education;

respect the dignity, rights, freedoms and legitimate interests of all participants of the educational process, observe ethical standards;

responsibly and carefully treat his/her health, the health of others, the environment;

adhere to the constituent documents, the internal regulations of the educational institution, as well as the terms of the agreement on the provision of educational services (if any);

to inform the management of the educational institution about the facts of bullying (harassment) in relation to the recipients of education, pedagogical, scientific-pedagogical, scientific workers, other persons involved in the educational process, witnessed by them personally, or persons who received reliable information from other persons (article 53$)^{29}$.

The issue of the liability of the pupils who evade attending school is discursive. The current legislation does not have any ideas about that. Liability for the child's truancy lays on the parents. According to the provision of the Code on administrative offences (article 184) the parents may be fined in case they do not provide the conditions for the child's education. Recently, educational and administrative legislation was amended with provisions of liability for school bullying. Bullying, committed by a child, is punished by a fine in case the offender is over 16 years old (Article 173-4). In other cases, the parents of the bully are fined. All the participants of the bulling case may receive psychological and pedagogical aid to overcome the negative consequences of the bulling.

Procedural status of the child varies according to the type of court procedure - criminal or civil.

${ }^{28}$ Короткова Л. П. Правовые вопросы приобщения подростка к труду. Правоведение. 1991. № 5. С. 86-89.

${ }^{29}$ Про освіту: Закон України від 05 вересня 2017 р. 2745-VIII. Відомості Верховної Ради України. 2017. № 38-39. Ст. 38. 
In criminal proceeding, the child may act as a suspect or defendant (a child in conflict with the law), a victim, a witness (a child in contact with the law). The procedure for criminal proceedings against juvenile suspect or defendant is determined by the general rules of criminal proceedings, taking into account the provisions of Chapter 38 "Criminal proceedings against minors", the Criminal Procedure Code of Ukraine (hereinafter - the CPC of Ukraine). Minors during criminal proceedings enjoy additional guarantees of respect and protection of their rights and legitimate interests (Article 10, paragraph 2 of the CPC). It should be noted that juvenile suspects or defendants are the target group for the system of procedural guarantees, while the rights of children in contact with the law (witnesses and victims) are to some extent overlooked by the legislator. The peculiarities of the legal status of the child in conflict with the law and the child in contact with the law require the establishment of special, child-friendly justice system.

In civil procedure, the child is entitled the same rights as the adult participant of the trial and the additional procedural rights, particularly (article 45, the Civil procedure code):

1) to express, directly or through a representative or legal representative, his/her opinion and to obtain assistance in expressing such an opinion;

2) to receive information about the trial through a representative or legal representative;

3) to exercise other procedural rights and perform the procedural duties stipulated by an international treaty, the consent of which is provided by the Verkhovna Rada of Ukraine.

The abovementioned rights are amended by the European Convention on the Exercise of Children's Rights, as the following: to apply for the appointment of a special representative (article 4). In proceedings affecting a child, the judicial authority, before taking a decision, shall:

a) consider whether it has sufficient information at its disposal in order to take a decision in the best interests of the child and, where necessary, it shall obtain further information, in particular from the holders of parental responsibilities;

b) in a case where the child is considered by internal law as having sufficient understanding:

- ensure that the child has received all relevant information;

- consult the child in person in appropriate cases, if necessary privately, itself or through other persons or bodies, in a manner appropriate to his or her understanding, unless this would be manifestly contrary to the best interests of the child;

- allow the child to express his or her views;

c) give due weight to the views expressed by the child (article 6). 
However, the implementation of these provisions in actual proceedings is not sufficient. The courts and judges rarely hear the child's opinion in cases involving the child.

However, the whole system of guarantees of the child's legal status is not ideal and requires approximation to the international juvenile standards.

\section{CONCLUSIONS}

The legal status of the child in Ukraine is a system of rights, freedoms and interests, as well as the duties and responsibilities of the special subject of law - the child, expressed in the values of natural law and the rules of positive law, guaranteed by the society and the state and in turn reflects international humanitarian standards for the rights of the child. Improvement of the normative basis of the general legal status of the child, legal and non-legal guarantees of realization of the rights, duties and responsibilities of the child, requires legislative-making activity of the state in order to fill the existing gaps, first of all - in the field of children who have a special juvenile status.

\section{SUMMARY}

In this paper the author defines general legal statuses of the child, outlines its scope and relationship with other legal statuses of a person, clarifies the structure of the legal status of the child and identifies gaps in legal regulation concerning children.

General legal status of a child and the constitutional and general legal status of a child are not identical, and the correlation between them can be described as a complex of general and particulate, where the part serves as a centre of the general phenomenon. In its turn, constitutional status of a child derives from the internationally recognized concept of the rights of a child, to be specific, from the four fundamental principles of the Convention on the rights of the child: non-discrimination and equality of rights of children; the best interests of the child; the right to survival and development; ensuring child participation in matters that concern he/her.

The general legal status of the child (juvenile status) is defined as a system of values expressed in the natural law and positive law norms guaranteed by the society and the state, and it contains human rights, freedoms and interests, as well as duties and responsibilities of a special entity the child.

\section{REFERENCES}

1. Declaration of the Rights of the Child. Adopted by UN General Assembly Resolution 1386 (XIV) of 10 December 1959. URL: http://www.un.org/cyberschoolbus/humanrights/resources/child.asp. 
2. World Declaration on the Survival, Protection and Development of Children, 1990. URL: https://www.unicef.org/wsc/declare.htm.

3. Грігорова Г.Л. Ювеналістична концепція реалізації негативної юридичної відповідальності неповнолітнім в Україні. Науковий вісник МГУ. Сер. : Юриспруденція. 2014. Вип. 10-1. С. 39-41.

4. Губаль Ю.В. Конституційно-правовий статус дитини в Україні та Угорщині: порівняльно-правове дослідження : автореф. дис. ... канд. юрид. наук : 12.00.02. Ужгород, 2015. 14 с.

5. Дутко А.О., Куліш Г.О. Сімейно-правовий статус батьків, які не досягли повноліття. Юридичний науковий електронний журнал. 2019. № 1. С. 68-71.

6. Кадегроб Л.О. Конституційно-правовий статус дитини в Україні: поняття та особливості. Вісник ОНУ імені I. I. Мечникова. Правознавство. 2018. Т. 23. Вип. 1(32). С. 15-21.

7. Китайка О.В. Гарантії прав і свобод дитини в Україні: поняття та зміст. Науковий вісник Міжнародного гуманітарного університету : зб. наук. пр. Сер. : «Юриспруденція». 2015. Вип. 13 (1). С. 50-52.

8. Китайка О.В. Конституційно-правовий статус дитини в Україні та міжнародні ювенально-правові стандарти: автореферат дис. ...канд. юрид. наук. 12.00.02. Одеса, 2018. С. 16.

9. Короткова Л.П. Правовые вопросы приобщения подростка к труду. Правоведение. 1991. № 5. С. 86-89.

10. Костенко Я.В. Правовий статус дитини в національному законодавстві. Актуальні проблем вітчизняної юриспруденції. 2018. № 1. С. 55-60.

11. Коталейчук С.П. Теоретико-правові проблеми правового статусу неповнолітніх в Україні та забезпечення його реалізації як один із основних напрямків діяльності міліції : автореф. дис. ... канд. юрид. наук: спец. 12.00.01. К., 2004. 20 с.

12. Кудрявцева О. Конституційні засади захисту прав і свобод дитини в Україні: досвід, проблеми, перспективи. Історико-правовий часопис. 2014. № 1. С. 49-53.

13. Кудрявцева О. М. Конституційно-правові основи захисту прав дитини в Україні : [монографія]. Київ : Арт Економі, 2015. 265 с.

14. Маніна М.А. Особисті права дитини. Актуальні проблеми вітчизняної юриспруденщії. 2013. Вип. 4. С. 49-56.

15. Маніна М. До питання про конституційні обов'язки дітей. Право України. 2007. № 11. С. 40-43.

16. Найман Н. Сімейно-правовий статус дитини. Підприємництво, господарство і право. 2016. № 6. С. 38-43.

17. О правах ребенка: Закон Республики Азербайджан от 19 мая 1998 г. 
18. Оніщенко Н.М., Львова О.Л., Сунєгін С.О. Права і свободи дитини: вступ до проблеми. Часопис Київського університету права. 2013. № 2. С. 13-17. Опольська Н.М. Види прав і свобод дитини. Науковий часопис НПУ імені М.П. Драгоманова. Серія 18 : Економіка $i$ право. 2010. Вип. 8. С. 151-157.

19. Оржаховська А.А. Конституційно-правовий статус дитини, яка перебуває в спеціальному навчальному закладі соціальної реабілітації : автореф. дис. ... канд. юрид. наук : 12.00.02. Кнїв, 2013. 20 с.

20. Про внесення змін до деяких законодавчих актів України щодо посилення соціального захисту дітей та підтримки сімей з дітьми: Закон України від 26.01.2016 № 936-VIII. Відомості Верховної Ради України. 2016. № 10. Ст. 99.

21. Про молодіжні та дитячі громадські організації: Закон України від 1 грудня 1998 р. Відомості Верховної Ради Украӥни. 1999. № 1. Ст. 2.

22. Про освіту: Закон України від 05 вересня 2017 р. 2745-VIII. Відомості Верховної Ради України. 2017. № 38-39. Ст. 38.

23. Рішення Конституційного Суду України у справі за конституційним поданням 50 народних депутатів України щодо офіційного тлумачення окремих положень частини першої статті 4 Цивільного процесуального кодексу України (справа про охоронюваний законом інтерес) 1 грудня 2004 р. № 18-рп/2004. Офіuійний вісник України. 2004. № 50. Ст. 3288.

24. Синєгубов О.В. Правовий статус дитини, як учасника особистих немайнових відносин. Форум права. 2013. № 1. С. 900-907. URL: http://nbuv.gov.ua/UJRN/FP_index.

25. Сімейний кодекс України. Відомості Верховної Ради України. 2002. № 21-22. Ст. 135.

26. Скакун О.Ф. Теорія держави і права (Енциклопедичний курс) : підручник. Харків : Еспада, 2006. 776 с.

27. Швець I.В. Конституційно-правовий статус дитини : поняття, елементи, види. Бюлетень Міністерства юстииії Украӥни. 2012. № 3. С. $116-123$.

28. Шульц О.А. «Права дитини» як категорія сучасного конституційного права. Часопис Київського університету права. 2009. № 3. C. 91-96.

Information about the author: Krestovska N. M., Doctor of Law, Professor at the Department of Maritime Law, National University "Odessa Maritime Academy” 8, Didrikhson str., Odessa, 65029, Ukraine 